The Corporate Social Performance of Developing Country Multinationals

\author{
Stelios Zyglidopoulos \\ Adam Smith Business School \\ University of Glasgow, Main Building, \\ Glasgow, G12 8QQ, Scotland, UK \\ Tel: 44 (0) 1413303993 \\ E-mail: szyglidopoulos@gmail.com \\ Peter Williamson \\ Cambridge Judge Business School \\ University of Cambridge \\ Trumpington Street Cambridge CB2 1AG UK \\ Tel: $44(0) 1223764229$ \\ E-mail: p.williamson@jbs.cam.ac.uk \\ And \\ Pavlos C. Symeou \\ School of Economics and Management \\ Cyprus University of Technology \\ 115 Spyrou Araouzou, 3036 Limassol \\ Cyprus \\ E-mail: pavlos.symeou@cut.ac.cy
}

Paper accepted for publication with Business Ethics Quarterly as of May 2016 


\title{
The Corporate Social Performance of Developing Country Multinationals
}

\begin{abstract}
In this paper, we explore the Corporate Social Performance (CSP) of Developing Country Multinationals (DMNCs). We argue that in competing internationally, DMNCs often face both reputation and legitimacy deficits, which they address by improving their CSP. We develop a series of hypotheses to explain the variation in CSP between DMNCs and domestic-only firms from developing countries and also examine variations in CSP between DMNCs depending on the extent of their multinationality and portfolio of host countries. Our findings support all our hypotheses, which suggest that DMNCs display enhanced levels of CSP compared to their domestic-only counterparts. CSP is also found to be positively related to the DMNCs' degree of multinationality, but with a declining incremental impact, whereas entry into developed markets leads to a greater improvement in DMNCs' CSP than expansion into developing markets. We highlight the implications of our findings for managers and researchers.
\end{abstract}

Key Words: Corporate Social Performance, Developing Country Multinationals. 


\section{The Corporate Social Performance of Developing Country Multinationals ${ }^{1}$}

\section{INTRODUCTION}

While the majority of studies on Corporate Social Performance (CSP) have dealt with firms from developed countries, in recent years there has been increased attention devoted to the CSP of firms from developing countries (Chapple and Moon, 2007, 2005; Visser, 2008; Gugler and Shi, 2009; Jamali and Mirshak, 2007; Baskin, 2006). Following Wood (1991: 693), we focus on developing country firms' CSP defined as "a business organization's configuration of principles of social responsibility, processes of social responsiveness, and policies, programs, and observable outcomes as they relate to the firm's societal relationships". Understanding the CSP of developing country firms is increasingly important for two reasons. First, developing country multinationals (DMNCs), which we define as firms headquartered in developing countries that operate foreign subsidiaries (Hitt et al. 1997, Kotabe et al. 2002), now account for a large proportion of overseas foreign direct investment (OFDI) globally (UNCTAD, 2014; Meyer and Thaijongrak, 2013) and, as such, their CSP has increasingly widespread implications. Second, as they internationalize, DMNCs face reputational and legitimacy challenges (Merz et al., 2010; Zaheer, 1995; Graafland, 2002; Gunningham et al., 2004) that they may try to address by improving their CSP.

In this paper, we investigate why and how the extent and nature of DMNC multinationality, defined as "business activities that span across national boundaries" (Tseng et al., 2007: 961), lead to changes in their CSP as compared to that of their counterparts operating only domestically. DMNCs venture abroad for several reasons.

\footnotetext{
${ }^{1}$ We would like to thank Bryan Husted and three anonymous reviewers for their valuable comments during the revision process.
} 
First, following the pattern established by multinationals from developed economies, DMNCs try to exploit competitive advantages they have developed at home (Cavusgil, 1980). These advantages might include technologies, brands or even CSP capabilities. However, previous research suggests that the competitive advantages DMNCs seek to exploit overseas are "non-traditional" including capabilities for: cost innovation (Zeng and Williamson, 2007; Williamson and Zeng, 2009); efficiently unlocking latent demand in low-end segments (Prahalad, 2006); optimizing products and processes for emerging markets (Ramamurti, 2012); dealing with weak institutions and infrastructure (Morck et al., 2008; Cuervo-Cazurra and Genc, 2008) or optimizing their value chains globally in ways that allow their low-cost talent and resources to be leveraged effectively in emerging markets (Williamson et al., 2013). The second main reason for DMNCs to internationalize is so-called "strategic asset seeking" (Rui and Yip, 2008; Deng, 2009; Makino et al., 2002). Internationalization can act as a springboard for DMNCs to acquire assets that may compensate for their competitive disadvantages, overcome late-comer disadvantage, counter-attack global rivals in their home market, by-pass trade barriers, alleviate domestic institutional constraints, secure preferential treatment from their home governments and access complementary assets to exploit their competitive advantages abroad (Luo and Tung, 2007).

These rationales for DMNCs venturing abroad would suggest that any shift in their CSP relative to that of their purely domestic cousins is likely to be a consequence, rather than a cause, of their internationalization. When DMNCs do venture abroad, there is evidence that they face both reputation and legitimacy deficits in the eyes of the various international stakeholders in the foreign countries in which they operate (Merz et al., 2010; Petersen and Pedersen, 2002; Zaheer, 1995; 
Gunningham et al., 2004). These deficits result from both the fact that DMNCs are foreign (a potential issue for all multinationals) and that they originate from developing countries. In investigating how DMNCs address these deficits, we develop a number of hypotheses concerning the variation in CSP between DMNCs and their counterpart domestic-only firms, and the variation in CSP between DMNCs as a result of the extent of their multinationality and portfolio of host countries.

We test our hypotheses using a sample of 412 firms headquartered in five developing countries (Brazil, Russia, India, China and South Africa) between 2009 and 2012 .

\section{THEORETICAL DEVELOPMENT}

In establishing themselves internationally, DMNCs often face two stakeholder-related issues: a legitimacy deficit and a reputational deficit (Merz et al., 2010; Petersen and Pedersen, 2002; Zaheer, 1995; Graafland, 2002; Gunningham et al., 2004), which they and their national counterparts do not face at home. We argue that DMNCs try to address both deficits by improving their CSP.

\section{The Legitimacy Deficit}

According to Suchman (1995: 574), legitimacy refers to the "generalized perception or assumption that the actions of an entity are desirable, proper, or appropriate within some socially constructed system of norms, values, beliefs, and definitions". Similarly, drawing on prior research, Deephouse and Carter (2005: 331) state that: "a central element of legitimacy, as currently understood, is meeting and adhering to the expectations of a social system's norms, values, rules, and meanings." Organizational legitimacy is a very valuable organizational resource that contributes to the long-term 
survival of firms (Ashforth and Gibbs, 1990; Suchman, 1995). Suchman (1995) identifies two forms of legitimacy, relevant for our purposes here: pragmatic legitimacy and moral legitimacy. Pragmatic legitimacy results from the self-interested behavior of stakeholders who will support a particular organization if they believe it is in their interest to do so. Moral legitimacy reflects stakeholders' normative evaluation (positive or negative) of the organization's activity, i.e. whether what the organization does is "the right thing to do" (Suchman, 1995: 579).

There are two factors that might negatively influence the legitimacy of DMNCs when they expand internationally: a liability of foreignness and hailing from a developing country. The liability of foreignness (Zaheer, 1995; Petersen and Pedersen, 2002; Bhanji and Oxley, 2013; Hymer, 1976) refers to "all additional costs a firm operating in a market overseas incurs that a local firm would not incur" (Zaheer, 1995: 343). This liability may result from a kind of economic nationalism that foreign firms often face. Stakeholders faced with a foreign firm entering their country might ask themselves 'does this firm adhere to our norms, values and meanings?' Their responses will impact the degree to which they support the foreign firm by providing it with the resources or demand necessary for its survival, which may give rise to legitimacy deficits (Mezias, 2002; Campbell et al., 2012).

DMNCs are likely to face more critical questioning of their legitimacy by foreign stakeholders who often hold negative perceptions of firms from developing countries. Stakeholders (from both developing and developed countries) might consider (other) developing-country firms to have lax environmental or labor standards and be subject to ownership or influence by non-transparent and possibly corrupt governments (Bilkey and Nes, 1982; Jaffe and Nebenzahl, 2006; Noorderhaven and Harzing, 2003). Of course, not all of these negative, often 
simplistic, stereotypes apply equally to all developing countries (Kotler et al., 1993). For example, the issue of corrupt links to government might be more serious in firms from Russia and State Owned Enterprises (SOEs) from China than for DMNCs from India and South Africa. However, even if there are significant differences in the effect that a particular developing country of origin might have on its DMNCs, there is substantial evidence in the literature that, on average, foreign firms from developing countries are associated with more negative stakeholder perceptions (Chinen et al., 2000; Loo and Davies, 2006; Verlegh and Steenkamp, 1999; Luo and Tung, 2007).

We can expect this joint influence of the liability of foreignness and developing country of origin on the legitimacy of DMNCs to operate through both the pragmatic and moral legitimacy channels that Suchman (1995) identifies. First, stakeholders might challenge the pragmatic legitimacy of DMNCs simply because they are foreign. For example, if customers have doubts about whether a foreign firm shares their own values and norms, they might hesitate to buy its products. They might challenge the firm's pragmatic legitimacy by asking themselves questions like: 'should we expose ourselves to the products of a firm whose values and norms we are not sure of?' Alternatively, state bureaucrats and politicians might ask themselves if it is in their country's interest to facilitate the entry of a foreign firm with uncertain values and norms. This challenge to the pragmatic legitimacy of foreign firms might be more severe for DMNCs because, coming from developing countries, they are often associated with low quality/cost products, fears that they might displace local production (Cordell, 1993; Aulakh et al., 2000) or even pose security threats (Lindsay 2015).

Second, stakeholders might ask themselves if it is morally acceptable for them to support a firm with questionable, or at least unknown, moral values, thus 
challenging the foreign firm's moral legitimacy. Again, such challenges to the moral legitimacy of foreign firms might be more intense in cases of DMNCs because of their association with home countries with poor track records in areas such as labor and environmental standards and corruption (Jaffe and Nebenzahl, 2006; Noorderhaven and Harzing, 2003; Visser, 2008). These negative perceptions of DMNCs can persist despite stakeholders acknowledging significant differences between firms across different countries and regions (Chambers et al., 2003; Brammer and Millington, 2005).

\section{The Reputation Deficit}

According to Fombrun (1996: 36), the reputation of a corporation is "the overall estimation in which a particular company is held by its various constituents." Despite being one of the most important intangible assets a firm can possess, a growing body of research suggests that a good reputation can help a firm gain sustainable competitive advantage leading to sustained superior financial returns (Dierickx and Cool, 1989; Fombrun and Shanley, 1990; Roberts and Dowling, 2002; Barney, 1991). A good corporate reputation can send a signal to consumers that a firm's products and services are of high quality, and hence justify a premium price (Shapiro, 1983). Corporate reputation can also help firms overcome crises by functioning as a "reservoir of goodwill" (Jones et al., 2000; Schnietz and Epstein, 2005).

In comparing the concepts of reputation and legitimacy, Deephouse and Carter (2005) find a number of similarities, including the fact that they are both stakeholder evaluations, they both share some of the same antecedents (i.e. size, philanthropy and strategic alliances) and they both enable firms to acquire resources. On the other hand, 
drawing on prior research (Lawrence, 1998; Ruef and Scott, 1998; Deephouse, 2000; Heugens et al., 2004), they maintain that a major difference is the fact that, while legitimacy is related to social acceptance and stems from stakeholder perceptions about whether a firm can be expected to adhere to, or comply with, social "norms, values, rules, and meanings" (Deephouse and Carter, 2005: 331), reputation is related to a perception of excellence and favorable standing which results from stakeholders comparing organizations to determine their "relative standing" in a relevant dimension. As Lawrence (1998: 1122) puts it: reputation "differentiates" the "outstanding" firms from the ranks of the merely "qualified", i.e. legitimate (cited in Deephouse and Carter, 2005: 332). Thus, while determinations of legitimacy can be seen as resulting from the question: 'is this organization acceptable to us?', those of reputation can be seen as resulting from the question: 'of these organizations, which one is better, in terms of $[\mathrm{X}]$ ?'

Given this distinction between legitimacy and reputation, we argue that when DMNCs enter foreign markets, in contrast to their national counterparts that do not operate abroad, they can be expected to suffer both deficits. First, due to their inherent liability of foreignness (Hymer, 1976; Zaheer, 1995), DMNCs will not have the established reputations of local, host-country firms. Most likely, DMNCs will be unfamiliar to host-country stakeholders (Campbell et al., 2012; Kostova and Zaheer, 1999), who could doubt their ability to perform as well as local firms. Second, because DMNCs are likely to face not only local firms, but also incumbent MNCs with generally stronger and established global reputations when they enter foreign markets, they will suffer a reputational deficit as unknown entities, relative to these established competitors (Nachum, 2010; Mathews, 2006). It can be argued that, generally speaking, MNCs have established global reputations with the stakeholders 
in a given country, even if they do not operate in that country. When Coca-Cola reentered Myanmar in 2013, for example, the company found that it had an established reputation with many consumers and other potential stakeholders as a result of its global activities, even though it had not been officially present in the country for over 60 years (Smith, 2013). This is something that is not the case with DMNCs that are relatively unknown before entering a foreign market.

The reputational deficit that DMNCs might suffer because they are unfamiliar with foreign target markets will be exacerbated if foreign stakeholders fill the gap in their knowledge with negative perceptions associated with DMNCs' developingcountry origins (Kostova and Zaheer, 1999; Campbell et al., 2012). As Luo and Tung (2007: 494) state, a developing country of origin could "tarnish organizational reputation and hinder shareholder confidence and relationship building with global stakeholders." so that DMNCs suffer from a negative halo effect (Jaffe and Nebenzahl, 2006; Noorderhaven and Harzing, 2003). Stakeholders of host countries might question the quality of the products or services of DMNCs given the extensive evidence that a country's economic development level plays an important role in the way the products of its firms are received internationally (Verlegh and Steenkamp, 1999; Chinen et al., 2000; Loo and Davies, 2006).

\section{The Potential of CSP to Mitigate Legitimacy and Reputational Deficits}

There are a number of reasons why DMNCs would try to make up for their legitimacy and reputation deficits by enhancing their CSP. First, there is a great deal of empirical evidence to suggest that good CSP has a positive impact on a firm's stock of intangible assets, including corporate reputation (Fombrun, 1996; Hall, 1992)

and legitimacy (Rao, 1994; Suchman, 1995). Second, researchers have also identified 
the ways in which CSP affects the reputation and legitimacy of firms operating across different countries in particular (Gardberg and Fombrun, 2006).

By enhancing its CSP, a firm can increase its legitimacy (Suchman, 1995; Deephouse and Carter, 2005), both pragmatic and moral. A firm's enhanced CSP can signal to its stakeholders that it has good values, norms and morals, prompting stakeholders to believe they can only benefit by supporting the firm (pragmatic legitimacy) and that they should support the firm (moral legitimacy). A number of researchers have confirmed this positive impact of improved levels of CSP on corporate legitimacy (Handelman and Arnold, 1999; Panwar et al., 2014; Du and Vieira Jr, 2012).

Given the legitimacy deficits that DMNCs are likely to face in host markets and the potential of CSP activities to address these deficits, we expect DMNCs to adjust their CSP activities with this aim in mind. As Gardberg and Fombrun (2006) have argued, firms operating across many countries can use positive CSP to increase their legitimacy. Gardberg and Fombrun (2006) use the term "corporate citizenship", which they see as part of CSP. We maintain that their arguments apply to CSP as well. CSP activities can help a firm's integration into a particular society (Etzioni, 2000) by creating public trust in the business (Harris et al., 2014; Fukuyama, 2000). This sociocognitive integration can be of particular help to firms operating across different countries, enabling them to overcome legitimacy deficits arising from nationalism associated with their "liability of foreignness" (Zaheer, 1995) and potential information asymmetries they might face (Siegel and Vitaliano, 2007; Darby and Karni, 1973; Nelson, 1970).

Moreover, in terms of a "license to operate", the "unwritten permit that society bestows on companies" (Thompson and Zakaria, 2004: 126), a number of researchers 
have argued that firms entering foreign markets often improve their CSP as a way to gain sufficient legitimacy to prompt various foreign stakeholders to "allow" them to operate in their new environments (Thompson and Zakaria, 2004; Gunningham et al., 2004).

CSP can also help firms address their reputational deficits. Fombrun (1996) contended that positive CSP might help firms build reputational capital, whereas Turban and Greening (1997) and Pfau et al. (2008) found that CSP improvements have positive effects on corporate reputation. Brown and Dacin (1997) have found that consumers see firms with enhanced CSP in a favorable light and Walter (2012) identified the conditions under which CSP tends to have a positive effect on corporate reputation. Additionally, Gardberg and Fombrun (2006) argued that in the same way as $\mathrm{R} \& \mathrm{D}$ and advertising expenditures can be considered investments in strategic differentiation, CSP can also be an investment in differentiation through a positive impact on corporate reputation (McWilliams and Siegel, 2000).

In sum, we expect that by enhancing their CSP, DMNCs will try to make up for their legitimacy deficits by obtaining a 'license to operate' in host markets and for their reputational deficits by showing that they are as good as local firms or MNCs by investing in enhancing their CSP. ${ }^{2}$ Hypothesis 1 follows:

\section{Hypothesis 1: DMNCs will demonstrate significantly more enhanced levels of CSP than their counterpart domestic (only) firms.}

\footnotetext{
${ }^{2}$ One could argue that DMNCs do not enhance their CSP in response to challenges abroad, but that developing country firms with enhanced CSP venture abroad because of their better CSP levels. However, we think this is quite unlikely based on the extensive literature on why DMNCs tend to venture abroad (Cavusgil, 1980; Deng, 2009; Prahalad, 2006; Williamson and Zeng, 2009), which does not include CSP as a major driver of internationalization.
} 
However, not all DMNCs experience legitimacy and reputational deficits in equal magnitude. We can expect the magnitude of the impact of these deficits to depend on the degree of the DMNC's multinationality (Hitt et al., 1997; Kotabe et al., 2002). In other words, the greater the multinationality of a DMNC, the greater the negative consequences of likely reputational and legitimacy deficits will be and the more the firm will try to ameliorate them by enhancing its CSP. This is for three reasons.

First, a firm is increasingly exposed to different attitudes and standards of what is right or wrong as its multinationality increases (Donaldson, 1996) and is more likely to suffer from a moral legitimacy deficit arising because its actions are not perceived to be "the right thing to do" (Suchman, 1995), in a particular national context. We can, therefore, expect DMNCs to enhance their CSP to match the level required by the most demanding of all the national environments in which they operate. Thus, the firm's CSP is enhanced as its multinationality increases because the likelihood of entering a country with legitimacy demands that are higher than those it had grown used to also rises as it extends its operations internationally.

Second, the greater the number of countries in which a DMNC operates, the greater its risk of suffering a negative "international corporate reputation side-effect" (Zyglidopoulos, 2002: 146). Given the increased cultural diversity a firm encounters as a result of increasing the number of countries it operates in, there is a greater risk that its activities in one country will create a negative spill-over on its reputation in other countries, possibly even harming its global reputation. In order to mitigate some of this risk, all multinationals, including DMNCs with their greater reputational deficits, might choose to maintain more enhanced CSP levels than local firms. 
Third, the increasing importance of non-governmental organizations (NGOs) in shaping the CSP environment for MNCs (Doh and Guay, 2006; Teegen et al., 2004) means that the likelihood of a firm becoming the target of an NGO campaign increases as it expands internationally (Ettenson and Gabrielle Klein, 2005). NGOs, as "organizational manifestations of broader social movements" (Teegen et al., 2004: 463), tend to target larger, more visible organizations (Rehbein et al., 2004). This is either due to the limited resources of NGOs that constrain them to only being able to detect the wrongdoings of larger, more visible corporations or that NGOs try to build their identity by positioning themselves against larger, more visible corporations (Rowley and Moldoveanu, 2003). Either way, as DMNCs expand internationally and their visibility increases, we can expect that they will be subject to increasing levels of scrutiny from NGOs, thus increasing the likelihood of becoming campaign targets (Rehbein et al., 2004; Ettenson and Gabrielle Klein, 2005). A good illustration of this point is the way that Jeff Ballinger chose Nike as a target for his famous campaign against the conditions of workers in developing countries. ${ }^{3}$ In 2000 , at the International Association for Business and Society (IABS) in Vermont, in a debate between Jeff Ballinger and representatives from the CSR department of Nike, Ballinger noted that, at the time (mid 1990s), Nike was no worse than other firms in the sports goods industry, but that he chose Nike because of its size and visibility. By choosing to focus on Nike, he said, he was able to influence more firms in the process (Wokutch, 2001). In an effort to protect themselves from becoming NGO targets, we can therefore expect DMNCs to engage more intensively in enhancing their CSP, the more multinational and visible they become (as found by Zyglidopoulos et al., 2012). Hypothesis 2 follows:

\footnotetext{
${ }^{3}$ We would like to thank one anonymous reviewer for bringing this example to our attention.
} 
Hypothesis 2: The greater the multinationality of DMNCs, the better their CSP will be.

As the level of multinationality of a DMNC increases, however, we can expect the incremental impact of entering an additional country on the level of CSP activities to reach a limit and then decline. This is for two reasons. First, once a DMNC reaches a high degree of multinationality, it is likely to have entered a market with relatively high legitimacy demands and will have already enhanced its CSP substantially to try to improve its legitimacy to levels necessary to satisfy stakeholders in this demanding market. It may still need to undertake additional local CSP activities in the new market it enters to bolster its legitimacy there, but it will not be necessary to enhance its overall corporate CSP activities. Second, as the degree of a DMNC's multinationality increases, the international corporate reputation side-effects (Zyglidopoulos, 2002) will begin to operate in the opposite direction to that outlined above, creating positive reputational spillovers. We can expect then that a DMNC's legitimacy and reputation deficits on entry to decline as multinationality increases, leading to a decreased need for enhanced CSP activities. Hypothesis 3 follows:

\section{Hypothesis 3: The incremental impact of greater multinationality on CSP will decline towards a limit.}

These relationships between multinationality and CSP are also likely to be impacted by the level of development of the countries a DMNC chooses to enter. If a DMNC internationalizes primarily by entering other developing-country markets, 
then the magnitude of its legitimacy deficit is likely to be low because stakeholder expectations are likely to be congruent with those it has already addressed in its home country (Cuervo-Cazurra and Genc, 2008). In contrast, if a DMNC enters developedcountry markets, even if CSP expectations vary, it is likely to encounter much higher stakeholder expectations and possibly higher levels of prejudice against its country of origin, leading to greater legitimacy and reputation deficits (Gaur et al., 2011). Therefore, when a DMNC enters developed-country markets, it will face more intense pressures to address the negative consequences of these deficits by means of enhancing its CSP activity in order to succeed there, as compared to entry into other developing markets. Hypothesis 4 follows:

\section{Hypothesis 4: DMNCs that operate relatively more in developed countries} (than in developing countries) will tend to have more enhanced CSP levels.

\section{METHODS}

\section{Sample and Data Collection}

We draw on the Thomson Reuters' ASSET4 database to obtain corporate financial and social performance data. Thomson Reuters' ASSET4 database is an established source of environmental, social and governance (ESG) information used for empirical research on CSP (Cheng et al., 2014; Ioannou and Serafeim, 2012). ASSET4 relies on a team of 125 specially trained analysts to collect data on over 500 separate data points from multiple sources, including company reports, filings and websites, NGO websites, CSR reports, and established and reputable media outlets, for a sample of over 3,500 globally traded public firms. These data points roll up into 226 key performance indicators (KPIs) that form the basis for the rating process of 
firms' three ESG performance pillars (Environmental Performance, Social Performance and Corporate Governance Performance). ASSET4 then transforms these data into objective and meaningful ratings through a weighting system that assigns weights to each KPI following several industry or regional considerations. To produce a firm's rating for each pillar, ASSET4 first sums the products of each KPI and its weight for each pillar. These scores are then normalized, adjusted for skewness and fitted to a bell curve to derive ratings between 0 and 100 .

We selected the whole universe of companies reported for five developing countries for the four year period between 2009 and 2012: Brazil (83 firms), Russia (32 firms), India (81 firms), China (83 firms) and South Africa (135 firms). We chose these particular developing countries as ASSET4 observes only very few firms from other developing countries. Furthermore, the data on these other countries are subject to missing values for variables pertinent to the current study. According to data from the World Bank's World Indicators data for 2012, our sample countries represent $42 \%$ of global population and $15 \%$ of global Gross National Income in constant 2005 US\$ (15.2\% Gross Domestic Income in constant 2005 US\$). Our initial sample consists of an unbalanced panel of 412 companies observed over the course of four years.

\section{Measures and Estimation Methods}

Dependent variable: We operationalize CSP using ASSET4's social pillar. According to Thomson Reuters, the social pillar measures a company's capacity to generate trust and loyalty amongst its workforce, customers and society through its use of management best practices. ASSET4 generates CSP scores by examining seven factors including employment quality, health and safety issues, training, diversity, human rights, community involvement and product responsibility. The measure is 
thus a reflection of the company's reputation and the health of its 'license to operate', which are key factors determining its ability to generate long-term shareholder value. The variable takes values between 0 and 100, with higher values reflecting better, positive CSP levels.

Independent variables: We measured firms' multinationality ('Hosts') by the number of countries in which firms had foreign subsidiaries in a given year based on information we collected from the sample firms' annual reports and publicly available documents. Drawing on this information, we developed a binary variable ('Foreign') that denotes whether a firm is a DMNC (i.e. has at least one foreign subsidiary) or not for testing H1. We used 'Hosts' to test $\mathrm{H} 2$ and also created the squared term of 'Hosts' ('Hosts_squared') to examine non-linearity in the relationship between 'Hosts' and CSP (H3). Lastly, we classified the DMNCs' host countries into developed and developing countries ${ }^{4}$ to calculate DMNCs' ratio of developed to developing host countries ('Ratio') for testing H4.

Control variables: To account for possible confounding factors, we control for a number of firm-level and country-level effects. At the firm level, we control for firm size ('Size') by including the number of employees of the firm as a deviation from its industry's mean. Given that the existence of a possible relationship between CSP and financial performance has been debated for more than 60 years (Ullmann, 1985; Waddock and Graves, 1997; Margolis and Walsh, 2003; Orlitzky et al., 2003; Bowman, 1975), we also control for financial performance using Return on Assets ('ROA').

We also control for industry membership ('Industry') with the expectation that firms that belong to the same industry will be more similar in terms of CSP than those

\footnotetext{
${ }^{4}$ We used the World Bank's classification system: http://data.worldbank.org/news/new-countryclassifications. Visited: 08/01/2015.
} 
in different industries. We used data from the Industry Classification Benchmark (ICB), maintained by FTSE International Limited, to classify sample firms by industry. ICB is a 4-digit classification framework designed to facilitate the comparison of companies across four levels of classification (Industry, Supersector, Sector and Subsector) and national boundaries. We chose the Supersector Level (2digit) to categorize our sample firms. At the country level, we used data obtained from the World Bank's World Development Indicators and the Heritage Foundation's databases to account for a country's economic, institutional and technological conditions and other demographic characteristics that delineate a firm's external environment that might influence its propensity and capability to engage in social activities. We used gross domestic product per capita ('GDP') to account for a country's economic conditions and the number of patent applications as a deviation from the sample countries' mean to account for technological environment ('Tech').

Based on data obtained from the World Bank, we considered controlling for other factors that were likely to be important, such as the quality of the institutional environment (a construct that captures multiple institutional attributes including the control of corruption, government effectiveness and regulatory quality, inter alia); the access of local population to the internet; the size of the population; and the country's degree of economic freedom. However, all these variables correlated strongly with GDP per capita (statistically significant correlation coefficients above 0.7 ), so we subsequently excluded them from the analysis. The high correlations between the sample countries' measures are no surprise because the sub-sample of developing countries in our available dataset exhibits similar levels of development in different areas (Hoskisson et al., 2013). This justifies our use of GDP per capita as a suitable, all-encompassing measure of development. Lastly, we create country dummies to 
indicate the country of origin and, due to the longitudinal nature of our dataset, we use annual dummies to account for unobserved effects.

\section{FINDINGS}

In Tables 1 and 2, we report the descriptive statistics and bivariate correlations of the variables. In our sample, there are 219 DMNCs (out of 412 firms) that had at least one foreign subsidiary. The correlations matrix suggests that firms with a foreign presence exhibit enhanced CSP levels (higher scores).

\section{$\underline{\text { Insert Table } 1 \text { about here }}$}

\section{$\underline{\text { Insert Table } 2 \text { about here }}$}

\section{Analysis}

Our data are clustered into three hierarchical levels: the firm level, the industry level, and the country level. Therefore, we model our data using a hierarchical linear model (HLM) in which we allow for dependence among the responses observed for units belonging to the same cluster (Rabe-Hesketh and Skrondal, 2012). By analyzing

our data using HLM, we decompose the total variance in CSP responses into between-cluster variance and within-cluster variance. The HLM estimator treats the cluster variables (country, industry and firm clusters) as random variables rather than model parameters and gives estimates of cluster-specific (random) intercepts. According to Rabe-Hesketh and Skrondal (2012), when the data exhibit hierarchical structures, the HLM estimator is more efficient than fixed-effects or random-effects estimators because it exploits both between- and within-cluster information. Running 
the likelihood-ratio test proposed by Wooldridge (2010) also suggested the presence of between-cluster variance, supporting our decision to use HLM with our data.

Several missing values for CSP, Industry and Size reduced the sample size to 387 firms (1313 observations). To determine whether or not the loss of sample firms was random, we tested for potential differences in the means of CSP, Size, FSTS, FATA and Hosts between firms omitted from the analysis and firms that were not. The analysis of means did not reveal any statistically significant differences across the two groups of firms, which suggests that our analysis does not suffer from a selection bias.

Table 2 shows very small correlation coefficients between the independent and control variables used in the analysis. The small correlations are also manifested in the small variance inflation factors (VIFs) we obtained when testing for the presence of serious collinearity. The VIFs' mean value is 2.21 and the highest VIF is 4.30, substantially lower than the widely accepted threshold of 10 and very close to the very strict threshold of 2.5 suggested by Allison (2012). Therefore, multicollinearity is not a concern.

\section{Results}

Our main independent variables and controls enter the regression models with one-year lags. This allows us to make a - preliminary - causal interpretation of our findings, but it consumes one year's observations. Table 3 shows the results of our analysis.

Our baseline, Model 0, includes all the firms (387) from developing countries in our sample and only the controls as independent variables. As expected, firm size is positively and significantly related to CSP. At the country level, higher levels of 
national development appear to be weakly conducive to improved firm CSP, whereas technological development appears to have a weak negative effect. Lastly, our year controls suggest that over time, the average CSP of sample firms has not improved compared to the base year (2010).

\section{Insert Table 3 about here}

Model 1, which also includes all developing country firms, tests $\mathrm{H} 1$ that proposes that DMNCs have significantly more enhanced levels of CSP than domestic (only) firms by adding Foreign to the controls model. Foreign is statistically significant $(\mathrm{p}<0.001 ; b=13.86)$, suggesting that on a scale of $0-100$, DMNCs have on average 13.86 units of CSP more than domestic-only firms, thus supporting H1. This translates to a predicted improvement in the CSP of DMNCs of $29 \%$ compared to that of domestic-only firms with a sample mean CSP of 47.6 units.

Model 2 tests $\mathrm{H} 2$, which proposes that DMNCs with a presence in relatively more foreign markets should experience improved levels of CSP. From this model and on, our sample size is reduced to 214 firms $^{5}$ and 515 observations, as we only include information on DMNCs. The effect of Hosts, a measure of the number of foreign markets in which a DMNC operates, is positive and statistically significant ( $\mathrm{p}<0.01 ; b=0.32$ ), supporting $\mathrm{H} 2$. If we consider the large magnitude of the coefficient of Foreign (Model 1), the small size of the effect of Hosts (Model 2) and that the preponderance of sample firms operate in relatively few foreign markets, we can infer that it is the initial forays abroad that provide the greatest encouragement to DMNCs to improve their CSP compared with later stages of international expansion. This is in

\footnotetext{
${ }^{5}$ The DMNCs in our sample were 219, but five firms were dropped from the analysis because they only had one-year observation.
} 
accordance with the projections of $\mathrm{H} 3$, which we then further tested by including both the levels and squared term of Hosts in Model 3. The two variables were centered around their mean to avoid creating a multicollinearity issue (Belsley, 1984). In this model, the coefficient for Hosts remains positive and statistically significant $(\mathrm{p}<0.01$; $b=1.04$ ), whereas the coefficient for its squared term is negative and statistically significant $(\mathrm{p}<0.05 ; b=-0.02)$. Combining these two results suggests that Hosts is nonlinearly related to CSP, which lends additional support to H3. The estimated relationship is illustrated in Graphs 1a (which shows how the predicted values for CSP in our sample firms vary as the number of host countries in which they operate increases) and Graph 1b, showing that the positive marginal effect of Hosts on CSP starts to decline from the second foreign market entry by a DMNC.

\section{$\underline{\text { Insert Graphs 1a and 1b about here }}$}

Finally, Model 4 tests H4 by including Ratio in the model (the DMNC's ratio of developed to developing host countries). The coefficient for Hosts remains positive and marginally statistically significant $(\mathrm{p}<0.1 ; b=0.23)$ and the coefficient for Ratio is also positive and statistically significant $(\mathrm{p}<0.05 ; b=3.12)$. These results lend support to $\mathrm{H} 4$, suggesting that both the number of host countries in which a DMNC operates and the balance between developed and developing host countries matter in determining its CSP. Our test for the interaction between these effects was statistically insignificant, suggesting that the two effects are independent.

\section{Robustness Checks}


We conducted numerous tests to examine the robustness of our analysis. First, to test the sensitivity of our results against alternative dimensions of a DMNC's social activities, we re-estimated our models using Corporate Environmental Performance (CEP) as the dependent variable, measured using the environmental pillar obtained from Thomson Reuters' ASSET4 database (reflecting a company's impact on living and non-living natural systems and ecosystems). The results of this analysis are shown in Table 4. The results for CEP are qualitatively similar to those derived from the main analysis.

\section{Insert Table 4 about here}

Our second robustness check sought to address the fact that our measure of multinationality, Foreign, required that a DMNC have at least one foreign subsidiary, but that firms without any foreign subsidiaries may still engage in international activities by exporting or through joint ventures. Clearly, it is possible that firms may interact with foreign stakeholders through these activities, just as DMNCs do and that these interactions might also present these firms with greater reputational and legitimacy deficits, compared to their domestic-only counterparts. To account for this possibility, we created a binary variable that classified firms engaged in other kinds of international activity (excluding those with at least one foreign subsidiary) as separate from purely domestic firms. We drew on ASSET4 data to measure Foreign Sales to Total Sales (FSTS), as well as firms' Foreign Assets to Total Assets (FATA). We gave a value of 1 to firms that had zero foreign subsidiaries and reported positive FSTS and/or FATA greater than 5\%. We then re-estimated Model 1 by adding this new variable as well as Foreign. Our results remained similar to those obtained in the 
main analysis while the new variable was positive, but statistically insignificant $(\mathrm{p}<0.3 ; b=1.91)$. This suggests that while developing country firms may interact with foreign stakeholders through foreign sales, only interactions that entail a physical foreign presence systematically induce firms to improve their CSP.

Our third robustness check was to test for Granger causality (Granger, 1969), i.e. whether the relationships between multinationality attributes and CSP/CEP are strictly unidirectional. We conducted this additional test even though our independent variables entered our main model with one-year lags. This was implemented by separately regressing all our main independent variables (i.e. Foreign, Hosts, Ratio), FSTS and FATA on their lagged values, the lagged values of CSP/CEP and all control variables to test whether lagged CSP/CEP drives multinationality. In all models, lagged CSP/CEP was statistically insignificant, suggesting a strictly unidirectional relationship between multinationality and CSP/CEP.

Lastly, we replaced ROA with return on equity (ROE) in the analysis. There were no major changes in the results. We also replaced the annual dummies with a time trend to predict the overall direction of CSP/CEP within the sample period. In all models for CSP, the time-trend was positive and statistically insignificant, whereas for CEP the time-trend was positive and statistically significant, consistent in both cases with the predictions associated with the annual dummies. The robustness of our empirical results to these sensitivity tests and alternative modeling gives us confidence in the empirical support we found for of all our hypotheses.

\section{DISCUSSION AND CONCLUSION}

In this paper, we explored why and how the extent and nature of multinationality of DMNCs leads to changes in their CSP compared to the CSP of 
their domestic-only counterparts. We found that in trying to address the reputational and legitimacy deficits they face in foreign markets, DMNCs display enhanced CSP levels compared to domestic-only firms in developing markets. Our findings indicate that the CSP of DMNCs is positively related to their multinationality, the incremental impact of which declines towards a limit and that the more DMNCs operate in developed countries, the greater the positive impact on CSP will be (as compared to the impact of internationalizing into other developing countries). These results contribute to the International Business (IB) and CSP literatures in a number of ways. With regard to the IB literature, our findings have a number of implications. First, we augment existing IB studies of the internationalization of DMNCs (Nachum, 2010; Williamson et al., 2013; Zeng and Williamson, 2007; Guillén and GarcíaCanal, 2009; Deng, 2009) by showing that a significant impact of increased multinationality is that it leads DMNCs to improve their CSP. Our empirical analysis supports this position that enhanced CSP is likely to be a consequence rather than a cause of DMNC internationalization. This position is in line with existing literature on the internationalization of DMNCs, which suggests that DMNCs expand abroad to either exploit the competitive advantages they have developed at home (Cavusgil, 1980; Williamson et al., 2013; Prahalad, 2006) or engage in "strategic asset seeking" (Rui and Yip, 2008; Deng, 2009).

Second, our hypotheses and results shed light on how the impact of internationalization on CSP might vary with the motivation of and strategies adopted by DMNCs. The classic model of internationalization postulates a strategy of incremental expansion and learning overseas, starting with similar markets and gradually moving to markets with less familiar characteristics, often termed the 'Uppsala model' (Johanson and Vahlne, 1977; Petersen et al., 2008; Johanson and 
Vahlne, 2009). More recent evidence on the behavior of DMNCs suggests that they might also (or alternatively) follow a strategy of asset-seeking in which the primary goal of internationalization is to access distinctive foreign resources to complement assets amassed at home (Ramamurti and Singh, 2009; Meyer and Thaijongrak, 2013; Williamson et al., 2013).

To the extent that DMNCs seek to minimize the challenges of learning about unfamiliar markets, we might expect them to focus on entering into other developing markets. In this case, it might be argued that internationalization would have little impact on DMNCs' CSP because their CSP would often already be superior to domestic competitors in the host countries they enter. We find, however, that DMNCs' internationalization does lead them to improve their CSP, even when they enter other developing markets, although less so than when they enter developed markets. One explanation for these results is that even when DMNCs enter other developing markets, they are likely to meet competition from multinationals from developed economies. Relative to these developed-country multinationals, they can be expected to face legitimacy and reputational deficits that we postulate they try to ameliorate by improving their CSP.

Our results also shed light on the impact that the entry of DMNCs in developed markets has on their CSP (Rui and Yip, 2008; Deng, 2012). The rationale for this behavior is to allow DMNCs to access strategic assets with qualities that allow them to catch up with the capabilities enjoyed by more experienced and betterresourced multinational competitors in global markets. Luo and Tung (2007) argue that this type of international expansion acts as a "springboard" upon which to acquire assets that may compensate for DMNCs' competitive disadvantages, overcome latecomer disadvantage, counter-attack global rivals in their home market, by-pass trade 
barriers, secure preferential treatment for companies that go abroad offered by their home governments and access complementary assets to exploit their competitive advantages overseas. To the extent that they pursue this strategy, DMNCs will need to operate in developed markets from the earliest stages of their internationalization. Our results suggest that this will lead DMNCs to systematically increase their investments in CSP as they expand internationally more than is predicted by the Uppsala model.

Third, we contribute to the literature on the liability of foreignness (Zaheer, 1995; Bhanji and Oxley, 2013; Gaur et al., 2011) by exploring how DMNCs try to address this issue. The existing literature suggests that in going abroad, DMNCs might try to overcome their liability of foreignness by drawing on their home government for support (Gaur et al., 2011), relying on their ownership-specific advantages or by increasing their isomorphism vis-à-vis local firms (Zaheer, 1995). Our findings suggest that enhancements in CSP is a significant way in which DMNCs try to overcome their liability of foreignness, especially when they enter developed markets.

We also contribute to the CSP literature in three ways. First, we extend the existing work investigating the drivers of CSP in developing countries. Extant literature maintains that the CSP of developing country firms is driven either by the pressures local firms face as a result of their roles as suppliers of global MNCs or because MNCs investing in developing countries respond to pressures from their home (developed country) stakeholders to enhance their CSP world-wide (Gugler and Shi, 2009; Visser, 2008). We explain the role that internationalization plays in positively influencing the CSP of DMNCs and how this impact varies according the level of development of the countries DMNCs enter. 
Second, we show that interactions with foreign stakeholders as a result of a foreign presence seem to be critical to stimulating CSP. Our findings suggest that developing country firms that sell abroad could also face reputational and legitimacy deficits that they may try to compensate for by making greater investments in CSP activities. However, even though the impact of a firm's foreign activities (excluding the operation of foreign subsidiaries) on CSP was found to be positive, it was statistically insignificant. This result extends the single-country finding of Barin Cruz et al. (2015) who found that the export intensity of Brazilian firms did not influence their engagement in CSP at the firm level of analysis. By testing this relationship using longitudinal data from five developing countries, our findings underscore the importance of a physical presence abroad in the form of foreign subsidiaries in stimulating DMNCs to significantly enhance their CSP.

Third, our findings suggest that CSP may create a cumulative and transferable strategic asset. We find that once DMNCs improve their CSP to meet the standards of one host country, the benefits of further incremental CSP improvements appear to gradually diminish as they enter additional countries (as confirmed by our findings in respect of $\mathrm{H} 3$ and $\mathrm{H} 4$ ). This may be because once the DMNC has achieved a competitive level of CSP in a host country (possibly through corporate initiatives), that level of CSP could create spillovers that influence the perception of stakeholders elsewhere in the world. Alternatively it may be that the DMNC follows a strategy of standardizing their best practices across the world (rather than following a multidomestic strategy), behavior observed by Dowell et al. (2000) in a study of environmental policies. In either case, a corollary of this finding is that if a DMNC chooses to enter developed countries with high expectations for CSP at an early stage in its internationalization, the incentive to make further improvements in CSP will be 
reduced as diminishing returns set in. These results are consistent with the idea that greater commitment to CSP creates a cumulative strategic asset that is transferable across countries a DMNC might subsequently enter. It is an asset that is especially valuable in light of the variance in expectations regarding CSP across different countries.

Our research has also implications for DMNC managers who are trying to expand the operations of their firms internationally. Interviews with senior management of DMNCs conducted by the authors in connection with other research indicate that DMNCs are fully cognizant of the reputational and legitimacy deficits they are likely to face when venturing abroad. The results we present in this paper suggest that a significant proportion of DMNC managers believe that CSP initiatives can provide a means of addressing these deficits. At minimum, managers of DMNCs need to take this into account when deciding on the level of their own investments in CSP in order to avoid potentially losing competitiveness to rival DMNCs using CSP investment to this end.

Moreover, our findings suggest that the likely need for DMNCs to increase investment in CSP when they venture abroad is significantly greater when they expand into developed markets than when they expand into developing markets. On the other hand, our results also suggest that DMNCs will reach a level of CSP at which point diminishing returns to further investment set in. Narrowing our focus to the role of higher CSP in neutralizing the reputational and legitimacy deficits DMNCs face when entering foreign markets, our results imply that the management of DMNCs needs to assess the point at which the incremental impact of additional investment in CSP reaches its limit. Of course, there may be other reasons for 
DMNCs to continue to increase investment in CSP (i.e. CSP may provide benefits to their home countries by increasing differentiation (McWilliams and Siegel, 2000)).

These results also suggest that increased investment in CSP should not be seen purely in terms of its impact on legitimacy and reputation in a particular, isolated host market. Rather, because our findings suggest that improving CSP creates a transferable strategic asset, the potential returns on investment in CSP need to be evaluated more broadly, taking into account a greater 'halo effect' that may help DMNCs overcome legitimacy and reputational deficits in other markets they may enter.

In spite of these contributions, our work presented here has a number of limitations that future research could address. First, our study is limited by the fact that we only investigate firms from five specific developing countries. While we do not expect firms from these countries to be unrepresentative of the population of developing country firms, we should add the caveat that this sample is biased towards larger economies and countries that are more advanced than many less-developed ones. It may be the case that firms from smaller or less-developed economies tend to pursue somewhat different internationalization strategies that, in turn, create different incentives for these firms regarding CSP. Moreover, in spite of our best efforts to collect all available data, we also could not account for our sample firms' type of international engagement. We could not, therefore, account for the type of subsidiary (i.e. sales, manufacturing), the kind of foreign entry involved (i.e. wholly owned subsidiary, joint venture), or the kind of strategy they followed (i.e. low cost, differentiation). Nor were we able to assemble data on the sequence in which each firm entered the different countries in which it operates. Future research could expand on our work by not only including firms from more developing countries, but also by 
conducting a more fine-grained investigation of the impact of the type of internationalization and strategy on changes in CSP.

Second, in this paper, we do not explore the role of institutional distance, the similarity or dissimilarity between the institutions of home and host countries on the drivers of CSP (Kostova, 1999; Kostova and Zaheer, 1999). Neither do we investigate the impact of potentially conflicting CSP expectations and institutional demands across host countries. We did not have the data or the space to adequately explore these issues. We hope that future researchers will be able to build on our research here and explore these potentially important influences on the CSP of DMNCs.

Third, we do not address the role that different regulatory environments have on the CSP of DMNCs, a limitation to be addressed by future research. Even though some aspects of CSP are regulated, we do not expect this limitation to profoundly impact our findings because most aspects are not regulated, as indicated by the existence of substantial variation in the levels of CSP between different companies.

Fourth, while we investigate the social performance of DMNCs by examining their CSP and CEP (captured by the social and environmental performance pillars of ASSET4, respectively), we do not engage in a more fine-grained investigation of any of the constituent dimensions to both CSP and CEP, nor do we directly measure the reputation and legitimacy deficits that we discuss. ASSET4 captures a firm's CSP by incorporating four such constituent dimensions (employment quality, health and safety, training and development, diversity, human rights, community and product responsibility), whereas the same database captures CEP by incorporating three such constituent dimensions (resource reduction, emission reduction and product innovation). Drawing on these dimensions, future research could attempt a more finegrained investigation of the differences between the social performance of DMNCs 
and local-only developing country firms. Such an investigation could provide us with a better understanding of the priorities that DMNCs have compared to other firms and possibly even reveal the limitations of investing in different kinds of CSP. Moreover, by finding ways to directly measure the reputation and legitimacy deficits that DMNCs face in entering foreign markets, future research can evaluate the direct impact that CSP can have in reducing such deficits.

A final limitation of our research is that we lack the data that would allow us to distinguish between the CSP levels of DMNCs in their home versus host countries, nor do we directly compare the CSP of DMNCs with MNCs. However, given the interconnectedness of our globalized environment, we assume that if DMNCs improve their CSP anywhere in the world, this will have an impact on their reputation and legitimacy everywhere they operate (a reasonable assumption in light of our finding that multinationality has a diminishing positive effect on DMNCs' CSP). Nonetheless, we might expect that CSP activities of DMNCs in their host markets might have a greater impact than CSP activities in their home markets. Moreover, directly comparing the CSP of DMNCs with that of MNCs could prove to be a potentially fruitful avenue for future research. 


\section{References}

Allison, P. D. 2012. Logistic regression using SAS: Theory and application. Cary, NC: SAS Institute.

Ashforth, B. E. \& Gibbs, B. W. 1990. The double-edge of organizational legitimation. Organization Science, 1: 177-94.

Aulakh, P. S., Rotate, M. \& Teegen, H. 2000. Export strategies and performance of firms from emerging economies: Evidence from Brazil, Chile, and Mexico. Academy of Management Journal, 43: 342-61.

Barin Cruz, L., Boehe, D. M. \& Ogasavara, M. H. 2015. CSR-based differentiation strategy of export firms from developing countries: An exploratory study of the strategy tripod. Business \& Society, 54: 723-62.

Barney, J. 1991. Firm resources and sustained competitive advantage. Journal of Management, 17: 99-120.

Baskin, J. 2006. Corporate responsibility in emerging markets. Journal of Corporate Citizenship, 24: 29-47.

Belsley, D. A. 1984. Demeaning conditioning diagnostics through centering. The American Statistician, 38: 73-77.

Bhanji, Z. \& Oxley, J. E. 2013. Overcoming the dual liability of foreignness and privateness in international corporate citizenship partnerships. Journal of International Business Studies, 44: 290-311.

Bilkey, W. J. \& Nes, E. 1982. Country-of-origin effects on product evaluations. Journal of International Business Studies, 13: 89-100.

Bowman, E. H. 1975. A strategic posture toward corporate social responsibility. California Management Review (pre-1986), 18(2): 49.

Brammer, S. \& Millington, A. 2005. Corporate reputation and philanthropy: An empirical analysis. Journal of Business Ethics, 61: 29-44.

Brown, T. J. \& Dacin, P. A. 1997. The company and the product: Corporate associations and consumer product responses. Journal of Marketing, 61: 68-84.

Campbell, J. T., Eden, L. \& Miller, S. R. 2012. Multinationals and corporate social responsibility in host countries: Does distance matter? Journal of International Business Studies, 43: 84-106.

Cavusgil, S. T. 1980. On the internationalization process of firms. European Research, 8: 273-81.

Chambers, E., Chapple, W., Moon, J. \& Sullivan, M. 2003. CSR in Asia: A seven country study of CSR website reporting. Working paper no 09-2003, International Centre for Corporate Social Responsibility, Nottingham.

Chapple, W. \& Moon, J. 2005. Corporate Social Responsibility (CSR) in Asia: A seven-country study of CSR web site reporting. Business \& Society, 44: 415-41.

Chapple, W. \& Moon, J. 2007. CSR agendas for Asia. Corporate Social Responsibility and Environmental Management, 14: 183-88.

Cheng, B., Ioannou, I. \& Serafeim, G. 2014. Corporate social responsibility and access to finance. Strategic Management Journal, 35: 1-23.

Chinen, K., Jun, M. \& Hampton, G. M. 2000. Product quality, market presence, and buying behavior: Aggregate images of foreign products in the US. Multinational Business Review, 8: 29-38.

Cordell, V. V. 1993. Interaction effects of country of origin with branding, price, and perceived performance risk. Journal of International Consumer Marketing, 5(2): 5-20. 
Cuervo-Cazurra, A. \& Genc, M. 2008. Transforming disadvantages into advantages: developing-country MNEs in the least developed countries. Journal of International Business Studies, 39: 957-79.

Darby, M. R. \& Karni, E. 1973. Free competition and the optimal amount of fraud. Journal of Law and Economics, 16: 67-88.

Deephouse, D. L. 2000. Media reputation as a strategic resource: An integration of mass communication and resource-based theories. Journal of Management, 26: 1091-112.

Deephouse, D. L. \& Carter, S. M. 2005. An examination of differences between organizational legitimacy and organizational reputation. Journal of Management Studies, 42: 329-60.

Deng, P. 2009. Why do Chinese firms tend to acquire strategic assets in international expansion? Journal of World Business, 44: 74-84.

Deng, P. 2012. The internationalization of Chinese firms: A critical review and future research. International Journal of Management Reviews, 14: 408-27.

Dierickx, I. \& Cool, K. 1989. Asset stock accumulation and the sustainability of competitive advantage: Reply. Management Science, 35: 1514.

Doh, J. P. \& Guay, T. R. 2006. Corporate social responsibility, public policy, and NGO activism in Europe and the United States: An institutional - stakeholder perspective. Journal of Management Studies, 43: 47-73.

Donaldson, T. 1996. Values in tension: Ethics away from home. Harvard Business Review, 74(5): 48-62.

Dowell, G., Hart, S. \& Yeung, B. 2000. Do corporate global environmental standards create or destroy market value? Management Science, 46: 1059-74.

Du, S. \& Vieira Jr, E. T. 2012. Striving for legitimacy through corporate social responsibility: Insights from oil companies. Journal of Business Ethics, 110: 413-27.

Ettenson, R. \& Gabrielle Klein, J. 2005. The fallout from French nuclear testing in the South Pacific: A longitudinal study of consumer boycotts. International Marketing Review, 22: 199-224.

Etzioni, A. 2000. Social norms: Internalization, persuasion, and history. Law and Society Review, 34: 157-78.

Fombrun, C. \& Shanley, M. 1990. What's in a name? Reputation building and corporate strategy. Academy of Management Journal, 33: 233-58.

Fombrun, C. J. 1996. Reputation: realizing value from the corporate image. Cambridge, MA: Harvard Business School Press.

Fukuyama, F. 2000. Trust: The social virtues and the creation of prosperity. Diane Publishing Company.

Gardberg, N. A. \& Fombrun, C. 2006. Corporate citizenship: Creating intangible assets across institutional environments. Academy of Management Review, 31: 329-46.

Gaur, A. S., Kumar, V. \& Sarathy, R. 2011. Liability of foreignness and internationalisation of emerging market firms. Advances in International Management, 24: 211-33.

Graafland, J. J. 2002. Profits and principles: four perspectives. Journal of Business Ethics, 35: 293-305.

Granger, C. W. J. 1969. Investigating causal relations by econometric models and cross-spectral methods. Econometrica, 37: 424-38. 
Gugler, P. \& Shi, J. Y. 2009. Corporate social responsibility for developing country multinational corporations: Lost war in pertaining global competitiveness? Journal of Business Ethics, 87: 3-24.

Guillén, M. F. \& García-Canal, E. 2009. The American model of the multinational firm and the "new" multinationals from emerging economies. The Academy of Management Perspectives, 23(2): 23-35.

Gunningham, N., Kagan, R. A. \& Thornton, D. 2004. Social license and environmental protection: Why businesses go beyond compliance. Law \& Social Inquiry, 29: 307-41.

Hall, R. 1992. The strategic analysis of intangible resources. Strategic Management Journal, 13: 135-44.

Handelman, J. M. \& Arnold, S. J. 1999. The role of marketing actions with a social dimension: Appeals to the institutional environment. Journal of Marketing, 63(3): 33-48.

Harris, J. D., Moriarty, B. \& Wicks, A. C. 2014. Public trust in business. Cambridge, UK: Cambridge University Press.

Heugens, P. P., Van Riel, C. \& Van Den Bosch, F. A. 2004. Reputation management capabilities as decision rules. Journal of Management Studies, 41: 1349-77.

Hitt, M. A., Hoskisson, R. E. \& Kim, H. 1997. International diversification: Effects on innovation and firm performance in product-diversified firms. Academy of Management Journal, 40: 767-98.

Hoskisson, R. E., Wright, M., Filatotchev, I. \& Peng, M. W. 2013. Emerging multinationals from mid - range economies: The influence of institutions and factor markets. Journal of Management Studies, 50: 1295-321.

Hymer, S. 1976. The international operations of national firms: A study of direct foreign investment. Cambridge, MA: MIT Press.

Ioannou, I. \& Serafeim, G. 2012. What drives corporate social performance? The role of nation-level institutions. Journal of International Business Studies, 43: 83464.

Jaffe, E. D. \& Nebenzahl, I. D. 2006. National image \& competitive advantage: The theory \& practice of place branding, $2^{\text {nd }}$ edition. Frederiksberg: Samfundslitterature Press.

Jamali, D. \& Mirshak, R. 2007. Corporate social responsibility (CSR): Theory and practice in a developing country context. Journal of Business Ethics, 72: 24362.

Johanson, J. \& Vahlne, J.-E. 1977. The internationalization process of the firm - A model of knowledge development and increasing foreign market commitments. Journal of International Business Studies, 8: 23-32.

Johanson, J. \& Vahlne, J.-E. 2009. The Uppsala internationalization process model revisited: From liability of foreignness to liability of outsidership. Journal of International Business Studies, 40: 1411-1431.

Jones, G. H., Jones, B. H. \& Little, P. 2000. Reputation as reservoir: Buffering against loss in times of economic crisis. Corporate Reputation Review, 3: 21-29.

Kostova, T. 1999. Transnational transfer of strategic organizational practices: A contextual perspective. Academy of Management Review, 24: 308-24.

Kostova, T. \& Zaheer, S. 1999. Organizational legitimacy under conditions of complexity: The case of the multinational enterprise. Academy of Management Review, 24: 64-81. 
Kotabe, M., Srinivasan, S. S. \& Aulakh, P. S. 2002. Multinationality and firm performance: The moderating role of R\&D and marketing capabilities. Journal of International Business Studies, 33: 79-97.

Kotler, P., Haider, D. \& Rein, I. 1993. Marketing places: Attracting investment, industry, and tourism to cities, states and nations. New York, NY: Simon \& Schuster.

Lawrence, T. B. 1998. Examining resources in an occupational community: Reputation in Canadian forensic accounting. Human Relations, 51: 1103-31.

Lindsay, J. R. 2015. The impact of China on cybersecurity: Fiction and friction. International Security, 39(3): 7-47.

Loo, T. \& Davies, G. 2006. Branding China: The ultimate challenge in reputation management? Corporate Reputation Review, 9: 198-210.

Luo, Y. \& Tung, R. L. 2007. International expansion of emerging market enterprises: A springboard perspective. Journal of International Business Studies, 38: 48198.

Makino, S., Lau, C.-M. \& Yeh, R.-S. 2002. Asset-exploitation versus asset-seeking: Implications for location choice of foreign direct investment from newly industrialized economies. Journal of International Business Studies, 33: 40321.

Margolis, J. D. \& Walsh, J. P. 2003. Misery loves companies: Rethinking social initiatives by business. Administrative Science Quarterly, 48: 268-305.

Mathews, J. A. 2006. Dragon multinationals: New players in 21st century globalization. Asia Pacific Journal of Management, 23: 5-27.

McWilliams, A. \& Siegel, D. 2000. Corporate social responsibility and financial performance: Correlation or misspecification? Strategic Management Journal, 21: 603-09.

Merz, M. A., Peloza, J. \& Chen, Q. 2010. Standardization or localization? Executing corporate philanthropy in international firms. International Journal of Nonprofit and Voluntary Sector Marketing, 15: 233-52.

Meyer, K. E. \& Thaijongrak, O. 2013. The dynamics of emerging economy MNEs: How the internationalization process model can guide future research. Asia Pacific Journal of Management, 30: 1125-53.

Mezias, J. M. 2002. Identifying liabilities of foreignness and strategies to minimize their effects: The case of labor lawsuit judgments in the United States. Strategic Management Journal, 23: 229-44.

Morck, R., Yeung, B. \& Zhao, M. 2008. Perspectives on China's outward foreign direct investment. Journal of International Business Studies, 39: 337-50.

Nachum, L. 2010. When is foreignness an asset or a liability? Explaining the performance differential between foreign and local firms. Journal of Management, 36: 714-39.

Nelson, P. 1970. Information and consumer behavior. The Journal of Political Economy, 78: 311-29.

Noorderhaven, N. G. \& Harzing, A.-W. 2003. The "country-of-origin effect" in multinational corporations: Sources, mechanisms and moderating conditions. Management and International Review, 47-66.

Orlitzky, M., Schmidt, F. L. \& Rynes, S. L. 2003. Corporate social and financial performance: A meta-analysis. Organization Studies, 24: 403-41.

Panwar, R., Paul, K., Nybakk, E., Hansen, E. \& Thompson, D. 2014. The legitimacy of CSR actions of publicly traded companies versus family-owned companies. Journal of Business Ethics, 125: 481-96. 
Petersen, B. \& Pedersen, T. 2002. Coping with liability of foreignness: Different learning engagements of entrant firms. Journal of International Management, 8: 339-50.

Petersen, B., Pedersen, T. \& Lyles, M. A. 2008. Closing knowledge gaps in foreign markets. Journal of International Business Studies, 39: 1097-113.

Pfau, M., Haigh, M. M., Sims, J. \& Wigley, S. 2008. The influence of corporate social responsibility campaigns on public opinion. Corporate Reputation Review, 11: 145-54.

Prahalad, C. K. 2006. The fortune at the bottom of the pyramid. New Delhi: Pearson Education India.

Rabe-Hesketh, S. \& Skrondal, A. 2012. Multilevel and longitudinal modeling using Stata. College Station, TX: Stata Press Books.

Ramamurti, R. 2012. What is really different about emerging market multinationals? Global Strategy Journal, 2: 41-47.

Ramamurti, R. \& Singh, J. V. 2009. Emerging multinationals in emerging markets. Cambridge: Cambridge University Press.

Rao, H. 1994. The social construction of reputation: Certification contests, legitimation, and the survival of organizations in the American automobile industry: 1895-1912. Strategic Management Journal, 15: 29-44.

Rehbein, K., Waddock, S. \& Graves, S. B. 2004. Understanding shareholder activism: Which corporations are targeted? Business \& Society, 43: 239-67.

Roberts, P. W. \& Dowling, G. R. 2002. Corporate reputation and sustained superior financial performance. Strategic Management Journal, 23: 1077-93.

Rowley, T. I. \& Moldoveanu, M. 2003. When will stakeholder groups act? An interest- and identity-based model of stakeholder group mobilization. Academy of Management Review, 28: 204-19.

Ruef, M. \& Scott, W. R. 1998. A multidimensional model of organizational legitimacy: Hospital survival in changing institutional environments. Administrative Science Quarterly, 4: 877-904.

Rui, H. \& Yip, G. S. 2008. Foreign acquisitions by Chinese firms: A strategic intent perspective. Journal of World Business, 43: 213-26.

Schnietz, K. E. \& Epstein, M. J. 2005. Exploring the financial value of a reputation for corporate social responsibility during a crisis. Corporate Reputation Review, 7: 327-45.

Shapiro, C. 1983. Premiums for high quality products as returns to reputations. The Quarterly Journal of Economics, 98: 659-79.

Siegel, D. S. \& Vitaliano, D. F. 2007. An empirical analysis of the strategic use of corporate social responsibility. Journal of Economics \& Management Strategy, 16: 773-92.

Smith, R. 2013. How to sell Coke to people who have never had a sip. http://www.npr.org/sections/money/2013/06/07/189184092/ (Accessed: Oct. 13, 2015).

Suchman, M. C. 1995. Managing legitimacy: Strategic and institutional approaches. Academy of Management Review, 20: 571-610.

Teegen, H., Doh, J. P. \& Vachani, S. 2004. The importance of nongovernmental organizations (NGOs) in global governance and value creation: An international business research agenda. Journal of International Business Studies, 35: 46383.

Thompson, P. \& Zakaria, Z. 2004. Corporate social responsibility reporting in Malaysia. Journal of Corporate Citizenship, 13: 125-136. 
Tseng, C.-H., Tansuhaj, P., Hallagan, W. \& McCullough, J. 2007. Effects of firm resources on growth in multinationality. Journal of International Business Studies, 38: 961-74.

Turban, D. B. \& Greening, D. W. 1997. Corporate social performance and organizational attractiveness to prospective employees. Academy of Management Journal, 40: 658-72.

Ullmann, A. A. 1985. Data in search of a theory: A critical examination of the relationships among social performance, social disclosure, and economic performance of US firms. Academy of Management Review, 10: 540-57.

UNCTAD 2014. World Investment Report 2014. United Nations.

Verlegh, P. W. \& Steenkamp, J.-B. E. 1999. A review and meta-analysis of countryof-origin research. Journal of Economic Psychology, 20: 521-46.

Visser, W. 2008. Corporate social responsibility in developing countries. In Crane, A., Matten, D., McWilliams, A., Moon, J. \& Siegel, D.S. (Eds.), The Oxford handbook of corporate social responsibility: 473-79. Oxford: Oxford University Press.

Waddock, S. A. \& Graves, S. B. 1997. The corporate social performance. Strategic Management Journal, 8: 303-19.

Walter, B. L. 2012. Does corporate social responsibility really contribute to reputation. Reputation Management, 55.

Williamson, P. J., Ramamurti, R., Fleury, A. \& Fleury, M. T. L. 2013. The competitive advantage of emerging market multinationals. Cambridge: Cambridge University Press.

Williamson, P. J. \& Zeng, M. 2009. Chinese multinationals: Emerging through new global gateways. In Ramamurti, R. \& Singh, J.V. (Eds.), Emerging multinationals in emerging markets: 81-109. Cambridge: Cambridge University Press.

Wokutch, R. E. 2001. Nike and its critics. Organization and Environment, 14: 20737.

Wood, D. J. 1991. Corporate social performance revisited. Academy of Management Review, 16: 691-718.

Wooldridge, J. M. 2010. Econometric analysis of cross section and panel data. MIT Press.

Zaheer, S. 1995. Overcoming the liability of foreignness. Academy of Management Journal, 38: 341-63.

Zeng, M. \& Williamson, P. J. 2007. Dragons at your door. Harvard Business School Press.

Zyglidopoulos, S. C. 2002. The social and environmental responsibilities of multinationals: Evidence from the Brent Spar case. Journal of Business Ethics, 36: $141-51$.

Zyglidopoulos, S. C., Georgiadis, A. P., Carroll, C. E. \& Siegel, D. S. 2012. Does media attention drive corporate social responsibility? Journal of Business Research, 65: 1622-27. 
Table 1: Summary statistics

\begin{tabular}{|c|c|c|c|c|c|}
\hline Variable & Description & Mean & SD & Min & Max \\
\hline Social & Corporate Social Performance & 56.28 & 30.99 & 4.11 & 97.07 \\
\hline Hosts & Total number of foreign host countries & 4.75 & 9.15 & 0 & 51 \\
\hline FATA & Foreign Assets to Total Assets & 8.20 & 17.02 & 0 & 100 \\
\hline $\begin{array}{l}\text { Developing } \\
\text { hosts }\end{array}$ & Number of developing host countries & 2.50 & 5.23 & 0 & 41 \\
\hline Developed hosts & Number of developed host countries & 2.25 & 4.97 & 0 & 35 \\
\hline Foreign & Binary indicating foreign presence or not & $214^{+}$ & & 0 & 1 \\
\hline $\mathrm{ROA}$ & Return on Assets & 8.41 & 8.42 & -18.95 & 118.74 \\
\hline Size & Number of employees as a deviation from industry average & 8228.22 & 75238.61 & -74983.43 & 523781.9 \\
\hline Industry & 2-digit Industry Classification Benchmark by FTSE & $28^{+}$ & & 5 & 95 \\
\hline Year & Year dummies & $4^{+}$ & & 2009 & 2012 \\
\hline Tech & $\begin{array}{l}\text { Country's number of patent applications as a deviation from sample } \\
\text { countries' average }\end{array}$ & 10661.69 & 52257.65 & -75260 & 166987 \\
\hline
\end{tabular}

${ }^{+}$absolute number 
Table 2: Pairwise correlations matrix

\begin{tabular}{|c|c|c|c|c|c|c|c|c|c|c|c|c|c|}
\hline & 1 & 2 & 3 & 4 & 5 & 6 & 7 & 8 & 9 & 10 & 11 & 12 & 13 \\
\hline 1. Social & 1 & & & & & & & & & & & & \\
\hline 2. Environmental & $0.8125^{*}$ & 1 & & & & & & & & & & & \\
\hline 3. Hosts & $0.2310 *$ & $0.2940 *$ & 1 & & & & & & & & & & \\
\hline 4. FSTS & $0.2801 *$ & $0.2901 *$ & $0.5727 *$ & 1 & & & & & & & & & \\
\hline 5. FATA & $0.2300 *$ & $0.2439 *$ & $0.5251 *$ & $0.7052 *$ & 1 & & & & & & & & \\
\hline $\begin{array}{l}\text { 6. Developing } \\
\text { hosts }\end{array}$ & $0.1996^{*}$ & $0.2518^{*}$ & $0.9016 *$ & $0.4590 *$ & $0.4955^{*}$ & 1 & & & & & & & \\
\hline $\begin{array}{l}\text { 7. Developed } \\
\text { hosts }\end{array}$ & $0.2147 *$ & $0.2757 *$ & $0.8903 *$ & $0.5727^{*}$ & $0.4398 *$ & $0.6057^{*}$ & 1 & & & & & & \\
\hline 8. Ratio & 0.0122 & 0.0655 & 0.0503 & $0.1932 *$ & -0.1073 & - $0.3318^{*}$ & $0.6057^{*}$ & 1 & & & & & \\
\hline 9. Foreign & $0.2879 *$ & $0.3158 *$ & $0.6663^{*}$ & $0.5965^{*}$ & $0.5864 *$ & $0.6137 *$ & $-0.3318 *$ & - & 1 & & & & \\
\hline 10. ROA & $0.1011^{*}$ & 0.0420 & 0.0489 & 0.0453 & -0.0191 & 0.0549 & $0.6137 *$ & -0.1044 & -0.0102 & 1 & & & \\
\hline 11. Size & 0.0632 & $0.1336^{*}$ & $0.0839 *$ & 0.0481 & 0.0147 & 0.0242 & 0.0549 & $0.1695^{*}$ & 0.0349 & $-\overline{0.1232 *}$ & 1 & & \\
\hline 12. Tech & $-0.1790^{*}$ & -0.1022 & -0.0451 & - $0.0678^{*}$ & -0.0583 & -0.0472 & 0.0242 & 0.0183 & -0.0647 & - $0.0988^{*}$ & $0.1170 *$ & 1 & \\
\hline 13. GDP & $0.2704 *$ & $0.1170 *$ & $-0.0675^{*}$ & -0.0033 & -0.0074 & 0.0053 & -0.0472 & $-0.2411 *$ & 0.0024 & -0.0041 & $-0.0745^{*}$ & -0.0687 & 1 \\
\hline
\end{tabular}

* Statistically significant at 0.05 
Table 3: Regressions results - Dependent variable: Corporate Social Performance

\begin{tabular}{|c|c|c|c|c|c|}
\hline & $\begin{array}{l}\text { Model 0 } \\
\text { (Control) } \\
\text { Coef./SE }\end{array}$ & $\begin{array}{l}\text { Model } 1\left(\mathrm{H}_{1}\right) \\
\text { Coef./SE }\end{array}$ & $\begin{array}{l}\text { Model } 2\left(\mathrm{H}_{2}\right) \\
\text { Coef./SE }\end{array}$ & $\begin{array}{l}\text { Model } 3\left(\mathrm{H}_{3}\right) \\
\text { Coef./SE }\end{array}$ & $\begin{array}{l}\text { Model } 4 \\
\left(\mathrm{H}_{4}\right) \\
\text { Coef./SE }\end{array}$ \\
\hline Foreign & & $\begin{array}{l}13.8670 * * * \\
(2.6509)\end{array}$ & & & \\
\hline Hosts & & & $\begin{array}{l}0.3202 * * \\
(0.1080)\end{array}$ & $\begin{array}{l}1.0472 * * \\
(0.3956)\end{array}$ & $\begin{array}{l}0.2310 \dagger \\
(0.1270)\end{array}$ \\
\hline Hosts_squared & & & & $\begin{array}{l}-0.0231^{*} \\
(0.0115)\end{array}$ & \\
\hline Ratio & & & & & $\begin{array}{l}3.1242 * \\
(1.4887)\end{array}$ \\
\hline ROA & $\begin{array}{l}-0.0021 \\
(0.0588)\end{array}$ & $\begin{array}{l}0.0093 \\
(0.0586)\end{array}$ & $\begin{array}{l}0.1561 * \\
(0.0726)\end{array}$ & $\begin{array}{l}0.1619 * \\
(0.0716)\end{array}$ & $\begin{array}{l}0.0128 \\
(0.1531)\end{array}$ \\
\hline Size & $\begin{array}{l}0.0001 * * * \\
(0.0000)\end{array}$ & $\begin{array}{l}0.0001 * * * \\
(0.0000)\end{array}$ & $\begin{array}{l}0.0001 * * \\
(0.0000)\end{array}$ & $\begin{array}{l}0.0001 * * \\
(0.0000)\end{array}$ & $\begin{array}{l}0.0001 \dagger \\
(0.0000)\end{array}$ \\
\hline GDP & $\begin{array}{l}0.0032 \\
(0.0027)\end{array}$ & $\begin{array}{l}0.0033 \\
(0.0026)\end{array}$ & $\begin{array}{l}0.0044 \dagger \\
(0.0024)\end{array}$ & $\begin{array}{l}0.0046 \dagger \\
(0.0024)\end{array}$ & $\begin{array}{l}0.0042 \\
(0.0029)\end{array}$ \\
\hline Tech & $\begin{array}{l}-0.0000 \dagger \\
(0.0000)\end{array}$ & $\begin{array}{l}-0.0000 \dagger \\
(0.0000)\end{array}$ & $\begin{array}{l}-0.0000 \\
(0.0000)\end{array}$ & $\begin{array}{l}-0.0000 \\
(0.0000)\end{array}$ & $\begin{array}{l}-0.0000 \\
(0.0000)\end{array}$ \\
\hline $\begin{array}{l}\text { Year control: } \\
2011\end{array}$ & $\begin{array}{l}-0.3333 \\
(0.9736) \\
0.7873\end{array}$ & $\begin{array}{l}-0.3243 \\
(0.9599) \\
0.7798\end{array}$ & $\begin{array}{l}-1.9149 \dagger \\
(1.1210) \\
-0.9403\end{array}$ & $\begin{array}{l}-2.0010 \dagger \\
(1.1158) \\
-1.3583\end{array}$ & $\begin{array}{l}-0.8207 \\
(1.4900) \\
-1.0083\end{array}$ \\
\hline 2012 & $(1.2623)$ & $(1.2362)$ & (1.3818) & (1.3771) & $(1.6980)$ \\
\hline Constant & $\begin{array}{l}40.1134 * * \\
(12.6067)\end{array}$ & $\begin{array}{l}34.3096^{* *} \\
(12.0211)\end{array}$ & $\begin{array}{l}39.0709 * * * \\
(11.2173)\end{array}$ & $\begin{array}{l}37.3061 * * * \\
(11.2601)\end{array}$ & $\begin{array}{l}43.3057 * * \\
(13.7869)\end{array}$ \\
\hline Observations & 918 & 918 & 515 & 515 & 515 \\
\hline Firms & $376^{\ddagger}$ & 376 & $214^{t t}$ & 214 & 214 \\
\hline Log likelihood & -3867.65 & -3854.49 & -2143.70 & -2096.10 & -1287.74 \\
\hline
\end{tabular}

$\dagger \mathrm{p}<0.1, * \mathrm{p}<0.05, * * \mathrm{p}<0.01, * * * \mathrm{p}<0.001$

Base control year: 2010. 
Table 4: Regressions results - Dependent variable: Corporate Environmental Performance

\begin{tabular}{|c|c|c|c|c|c|}
\hline & $\begin{array}{l}\text { Model 0 } \\
\text { (Control) } \\
\text { Coef./SE }\end{array}$ & $\begin{array}{l}\text { Model } 1\left(\mathrm{H}_{1}\right) \\
\text { Coef./SE }\end{array}$ & $\begin{array}{l}\text { Model } 2\left(\mathrm{H}_{2}\right) \\
\text { Coef./SE }\end{array}$ & $\begin{array}{l}\text { Model } 3\left(\mathrm{H}_{3}\right) \\
\text { Coef./SE }\end{array}$ & $\begin{array}{l}\text { Model } 4 \\
\left(\mathrm{H}_{4}\right) \\
\text { Coef./SE }\end{array}$ \\
\hline Foreign & & $\begin{array}{l}16.8038 * * * \\
(2.6235)\end{array}$ & & & \\
\hline Hosts & & & $\begin{array}{l}0.4602 * * * \\
(0.1108)\end{array}$ & $\begin{array}{l}1.2174 * * \\
(0.4123)\end{array}$ & $\begin{array}{l}0.3706 * * \\
(0.1334)\end{array}$ \\
\hline Hosts_squared & & & & $\begin{array}{l}-0.0215 \dagger \\
(0.0120)\end{array}$ & \\
\hline Ratio & & & & & $\begin{array}{l}2.6752 \dagger \\
(1.6128)\end{array}$ \\
\hline $\mathrm{ROA}$ & $\begin{array}{l}-0.0107 \\
(0.0561)\end{array}$ & $\begin{array}{l}0.0003 \\
(0.0558)\end{array}$ & $\begin{array}{l}0.0998 \\
(0.0728)\end{array}$ & $\begin{array}{l}0.1038 \\
(0.0734)\end{array}$ & $\begin{array}{l}0.2018 \\
(0.1489)\end{array}$ \\
\hline Size & $\begin{array}{l}0.0001 * * * \\
(0.0000)\end{array}$ & $\begin{array}{l}0.0001 * * * \\
(0.0000)\end{array}$ & $\begin{array}{l}0.0001 * * \\
(0.0000)\end{array}$ & $\begin{array}{l}0.0001 * * \\
(0.0000)\end{array}$ & $\begin{array}{l}0.0001 * \\
(0.0000)\end{array}$ \\
\hline GDP & $\begin{array}{l}0.0006 \\
(0.0022)\end{array}$ & $\begin{array}{l}0.0008 \\
(0.0021)\end{array}$ & $\begin{array}{l}0.0025 \\
(0.0022)\end{array}$ & $\begin{array}{l}0.0024 \\
(0.0021)\end{array}$ & $\begin{array}{l}0.0024 \\
(0.0027)\end{array}$ \\
\hline Tech & $\begin{array}{l}-0.0000 \\
(0.0000)\end{array}$ & $\begin{array}{l}-0.0000 \\
(0.0000)\end{array}$ & $\begin{array}{l}-0.0000 \\
(0.0000)\end{array}$ & $\begin{array}{l}-0.0000 \\
(0.0000)\end{array}$ & $\begin{array}{l}-0.0001 * * \\
(0.0000)\end{array}$ \\
\hline $\begin{array}{l}\text { Year control: } \\
2011\end{array}$ & $\begin{array}{l}1.4651 \dagger \\
(0.8877)\end{array}$ & $\begin{array}{l}1.4671 \dagger \\
(0.8815)\end{array}$ & $\begin{array}{l}0.7156 \\
(1.1057)\end{array}$ & $\begin{array}{l}0.7522 \\
(1.1221)\end{array}$ & $\begin{array}{l}1.9022 \\
(1.4226)\end{array}$ \\
\hline 2012 & $\begin{array}{l}3.8815 * * * \\
(1.1316)\end{array}$ & $\begin{array}{l}3.8403 * * * \\
(1.1192)\end{array}$ & $\begin{array}{l}3.5206 * * \\
(1.3500)\end{array}$ & $\begin{array}{l}3.5513 * * \\
(1.3674)\end{array}$ & $\begin{array}{l}3.8918 * \\
(1.6187)\end{array}$ \\
\hline Constant & $\begin{array}{l}38.9475 * * * \\
(10.2467)\end{array}$ & $\begin{array}{l}31.8739 * * \\
(10.0111)\end{array}$ & $\begin{array}{l}34.0583 * * * \\
(10.0417)\end{array}$ & $\begin{array}{l}32.9646 * * * \\
(9.8734)\end{array}$ & $\begin{array}{l}34.2460 * * \\
(12.6987)\end{array}$ \\
\hline Observations & 918.00 & 918.00 & 515.00 & 515.00 & 515.00 \\
\hline $\begin{array}{l}\text { Firms } \\
\text { Log likelihood }\end{array}$ & $\begin{array}{l}376^{\ddagger} \\
-3836.53\end{array}$ & $\begin{array}{l}376 \\
-3817.10\end{array}$ & $\begin{array}{l}214^{\dagger} \\
-2149.48\end{array}$ & $\begin{array}{l}214 \\
-2106.52\end{array}$ & $\begin{array}{l}214 \\
-1286.29\end{array}$ \\
\hline
\end{tabular}

$\dagger \mathrm{p}<0.1, * \mathrm{p}<0.05, * * \mathrm{p}<0.01, * * * \mathrm{p}<0.001$

Base control year: 2010. 
Graph 1(a) and (b): The non-linear effect of Hosts on CSP
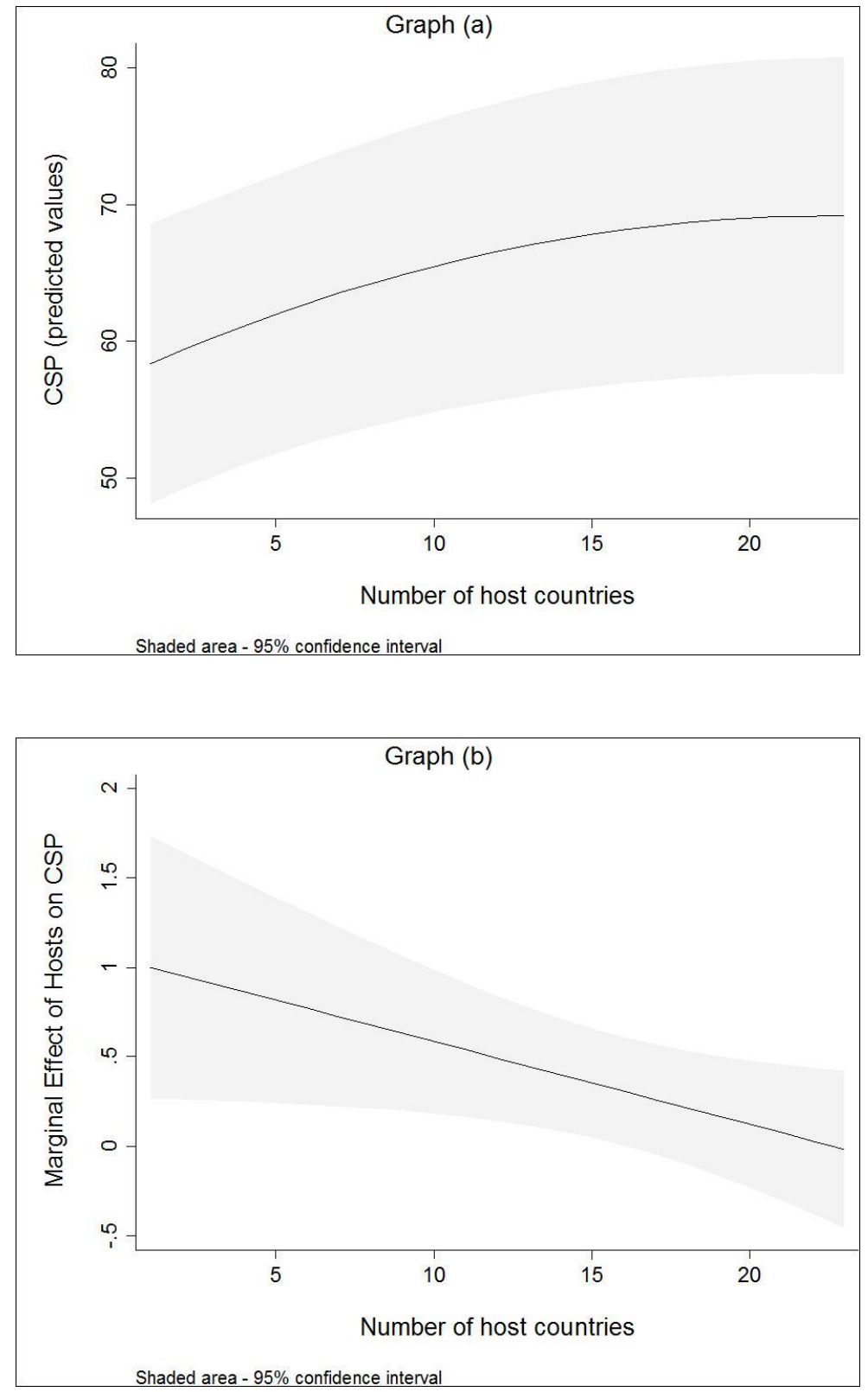